\title{
Performance of Cabbage (Brassica oleracea L. var. capitata) in Relation to Fertigation using Variable Rates and Sources of Fertilizers
}

\author{
A. K. Nair ${ }^{*}$, S. S. Hebbar, M. Prabhakar, M. Senthilkumar and R. S. Rajeshwari \\ Division of Vegetable Crops, ICAR-Indian Institute of Horticultural Research, Hessarghatta \\ Lake, Bangalore, Karnataka, India \\ *Corresponding author
}

\begin{abstract}
A B S T R A C T
A field experiment was conducted to study the effect of fertigation on the performance of Cabbage variety Unnati at ICAR-Indian Institute of Horticultural Research, Bengaluru during rabi of 2013 and 2014. The experiment was laid out in Randomized Block Design with three replications and consisted of total ten treatments, which included different doses, sources of fertilizers and its frequency of application. The pooled analysis of two years data revealed that the application of fertilizer dose (150:100:125 kg NPK ha ${ }^{-1}$ ) through fertigation using water soluble fertilizers on weekly interval resulted in higher values for plant height $(29.56 \mathrm{~cm})$, leaves per plant $(25.67)$ and leaf weight per plant (599.30 gm) at 60 days after transplanting, which remained on par with the same dose and source applied at bi-weekly interval. Similarly, these two treatments recorded higher values for head weight (454.0 and $423.6 \mathrm{~g})$, stem weight (102.3 and $94.0 \mathrm{~g}$ ) and root weight (66.67 and $45.67 \mathrm{~g})$ at harvest. All the fertigation treatments recorded higher yields over the conventional soil application of fertilizers to the tune of $6.5-60.3$ per cent. Among the fertigation treatments, application of 100 per cent recommended dose using water soluble fertilizers at weekly interval resulted in significantly higher yield $(60.86 \mathrm{t}$ $\mathrm{ha}^{-1}$ ) than all the other treatments tested except the treatment where the bi-weekly application of same dose of fertilizer through the same sources $\left(58.82 \mathrm{t} \mathrm{ha}^{-1}\right)$ was done.
\end{abstract}

Keywords

Cabbage,

Fertigation,

Growth, Yield,

Water use

efficiency,

Economics

Article Info

Accepted:

10 October 2020

Available Online:

10 November 2020

\section{Introduction}

Cabbage is one of the most popular vegetables grown in India. It is grown in 3.98 lakh hectares with a production of 90.37 lakh tonnes and a productivity of 22.70 tonnes per hectare (NHB, 2018). The major cabbage producing states are West Bengal, Odisha, Madhya Pradesh, Bihar, Assam, Gujarat and Uttar Pradesh. Cabbage is used as salad, boiled vegetable and dehydrated vegetable as well as in cooked curries and pickles. Cabbage is rich in minerals and vitamins $\mathrm{A}$, $\mathrm{B}_{1}, \mathrm{~B}_{2}$ and $\mathrm{C}$ (Hanif et al., 2006).

Land, water and fertilizers are the important inputs for agricultural production systems and special attention is required for economic and efficient use of these limited and costly resources. About two thirds of the increase in production of food and fibre needed to satiate the increase in demand of the increasing 
population has been attributed to irrigation. Drip irrigation is the most efficient system of irrigation in terms of economising the use of water by wetting the root zone of the crop (Sezen et al., 2006). Vegetable production can be made more economical and efficient by adoption of micro irrigation methods which increases the crop yield to the tune of 25-30 per cent with 50 to 60 per cent saving of irrigation water over the conventional irrigation system (Yadav et al., 1993).

Fertigation is an eco-friendly and sustainable method of dispensing nutrients to the crop near the active root zone that increases crop productivity, quality and resource use efficiency. It is the most effective way to supply water and nutrients to the plant which not only saves water but also increases yield of fruits and vegetable (Spehia et al., 2010). Studies have indicated that the fertilizer should be applied regularly and timely in small amounts for better plant growth and yield (Neeraja et al., 1999). The cabbage crop responded well to $\mathrm{N}$ and $\mathrm{K}$ fertigation compared to soil application of recommended dose of fertilizers (Vasu and Reddy, 2013). Scientific information on fertigation especially on Rabi grown cabbage is very less, hence the present study was undertaken to determine the effect of fertigation of recommended dose of fertilizers and sources through drip irrigation for its commercial production.

\section{Materials and Methods}

The experiment was conducted at ICARIndian Institute of Horticultural Research, Hessarghatta, Bengaluru, Karnataka, India during rabi of 2013 and 2014. The institute is situated at $13^{0} 7^{\prime} \mathrm{N}$ latitude, $72^{0} 29$ 'E longitude and an elevation of 890 meters above mean sea level. The experimental soil was well drained sandy loam $(\mathrm{pH} 6.60$ and electrical conductivity $0.25 \mathrm{dSm}^{-1}$ ) characterized by medium organic carbon $(0.63 \%)$, low available $\mathrm{N}\left(169 \mathrm{~kg} \mathrm{ha}^{-1}\right)$, high available $\mathrm{P}$ (78 $\left.\mathrm{kg} \mathrm{ha}{ }^{-1}\right)$ and medium available $\mathrm{K}$ (260 $\left.\mathrm{kg} \mathrm{ha}^{-1}\right)$. The soil has available water holding capacity of $130 \mathrm{~mm}$ in one meter soil depth. The experiment was laid out in Randomized Block Design with ten treatments and three replications. Prior to planting, a uniform amount of farm yard manure @ 25 tonnes hectare $^{-1}$ was applied as basal application to all the treatments as common practice. The treatment details and quantity of different fertilizers applied have been given in Table 1 and 2. Urea, Polyfeed (19:19:19), Sulphate of potash and Muriate of potash were used as water soluble fertilizers for treatments $T_{3}$ to $\mathrm{T}_{10}$, while urea, single super phosphate and muriate of potash were used as common fertilizers for treatments $T_{1}$ and $T_{2}$. The entire dose of $\mathrm{P}$ and half of $\mathrm{N}$ and $\mathrm{K}$ were applied as basal and remaining half of $\mathrm{N}$ and $\mathrm{K}$ was side dressed to soil at in equal splits 30 and 60 days after transplanting in $\mathrm{T}_{1}$. The 30 days old seedlings of cabbage cultivar "Unnati" were transplanted at $80-40 \times 30 \mathrm{~cm}$ plant to plant spacing, under paired row system during the first week of November during both the years. Drip irrigation was given depending on the rate of evaporation and amount of effective rainfall received. It worked out to be $310 \mathrm{~mm}$ and $280 \mathrm{~mm}$ of supplemental irrigation water for first and second year of cropping season after making necessary adjustment for the effective rainfall received. The fertigation treatments started after two weeks of planting and fertilizers were applied through drip system at weekly and bi-weekly interval. The treatments were imposed dissolving desired amounts of fertilizers and applied via venturi system through drip irrigation to the field. A total of 13 and 26 numbers of fertigations were given for weekly and bi-weekly interval, which was continued up to 15 days before completion of crop growth period. Five plants per replication in each of the treatments were selected randomly for recording yield 
parameters. Recommended package of practices including agronomic and plant protection measures were adopted to raise the crop (Prabhakar et al., 2010). The experimental data were statistically analysed (Gomez and Gomez, 1983) and compared using critical difference at five per cent probability level.

\section{Results and Discussion}

The data pertaining to plant growth, yield and yield attributing characters are presented in Table 3. The plants were taller (24.74 to 29.56 $\mathrm{cm})$ and the values for plant spread where higher $(32.26$ to $38.33 \mathrm{~cm})$, when the water soluble fertilizers applied through drip irrigation in split doses compared to soil application of fertilizers $(23.59$ and $30.65 \mathrm{~cm})$ at 60 days after transplanting. Application of 100 per cent recommended dose of fertilizers through fertigation at weekly interval $\left(\mathrm{T}_{3}\right)$ recorded significantly taller plants $(29.56 \mathrm{~cm})$ than most of the treatments except $\mathrm{T}_{4}(29.23$ $\mathrm{cm}), \mathrm{T}_{7}(29.34 \mathrm{~cm})$ and $\mathrm{T}_{8}(28.80 \mathrm{~cm})$. The significantly shortest plants were observed with soil application of common fertilizers $(23.59 \mathrm{~cm})$. Similarly, $\mathrm{T}_{3}$ also recorded significantly higher plant spread of $38.33 \mathrm{~cm}$, which remained on par with $\mathrm{T}_{7}$ i.e application of same amount of water soluble fertilizers through fertigation on bi-weekly basis (37.47 $\mathrm{cm})$. Increased plant height and spread with the application of $100 \%$ fertilizer dose (150:100:125 kg NPK ha ${ }^{-1}$ ) in 13 equal splits at 7 days intervals given at different stages might be due to availability of sufficient quantity of major nutrients, which subsequently resulted in higher values for plant height and spread. Other than this, higher frequency of irrigation and increased availability of soil moisture under drip irrigation coupled with fertigation might have led to effective absorption and utilization of these nutrients and better proliferation of roots resulting in better plant height and spread. The results are in conformity with Rakh (1992), Sanchita et al., (2004), Singh et al., (2006), Shinde et al., (2006) and Tanpure et al., (2007).

The pooled data analysis revealed that $T_{3}$ (application of $100 \%$ NPK fertigation through water soluble fertilizers at weekly interval) recorded significantly higher number of leaves per plant (25.67) than $\mathrm{T}_{1}, \mathrm{~T}_{2}$ and $\mathrm{T}_{10}$. The lowest number of leaves per plant observed with $\mathrm{T}_{1}$ (17.67). Kapoor et al., (2014) and Yanglem and Tumbare (2015) also recorded higher number of leaves at higher levels of fertigation treatments than soil application of fertilizer with drip irrigation in cauliflower. Nitrogen is an important constituent of chlorophyll and proteins which is vital for vegetative growth. Phosphorus and potassium play a key role in physiological processes viz., photosynthesis, respiration, energy storage, cell division and cell enlargement (Sharma, 2016). Increase in number of leaves per plant might be attributed to balanced fertilization. Similar results have been reported by Sharma and Sharma (2010), Kumar et al., (2013) and Shree et al., (2014) in cauliflower.

The same treatment i.e. $\mathrm{T}_{3}$ recorded significantly higher values for leaves weight per plant $(599.3 \mathrm{~g})$ than $\mathrm{T}_{1}(360.0 \mathrm{~g}), \mathrm{T}_{2}$ (395.0g) and $\mathrm{T}_{10}(429.0 \mathrm{~g})$. The observations taken at the time of harvest showed that stem and root weight was significantly higher (102.3 and 66.67g) with application of 100 per cent fertigation of recommended dose of macro nutrients using water soluble fertilizers given at weekly interval $\left(\mathrm{T}_{3}\right)$ than all other treatments, which was followed by $\mathrm{T}_{4}$ and $\mathrm{T}_{7}$ $(94.00 \mathrm{~g})$ for stem and $\mathrm{T}_{4}(46.33 \mathrm{~g})$ and $\mathrm{T}_{7}$ $(45.67 \mathrm{~g})$ for the root weight. The lower values for stem $(38.3,45.0 \mathrm{~g})$ and root $(26.33$, $32.67 \mathrm{~g})$ were observed with soil application of fertilizers $\left(T_{1}\right)$ and fertigation with common fertilizers $\left(T_{2}\right)$, respectively. Naher 
et al., (2014) recorded maximum root and stem weight at the time of harvest with NPK fertilization. This might be due to extended split application of nitrogen and potassium fertilizers up to 60 DAT increased the use efficiency of added nutrients which enhanced the uptake of these nutrients resulted more vegetative growth.

The head diameter of cabbage is a vital parameter which influences the head size and its market value. Larger diameter of head fetches better market quality of cabbage as well as processing (Table 3). The significantly higher head diameter was recorded with $\mathrm{T}_{3}$ $(13.30 \mathrm{~cm})$, which remained on par with only $\mathrm{T}_{4}(12.88 \mathrm{~cm})$ and $\mathrm{T}_{7}(12.99 \mathrm{~cm})$, while $\mathrm{T}_{1}$ recorded the lowest values for head diameter $(9.93 \mathrm{~cm})$. Higher uptake of nutrients may have resulted in higher diameter of head. These results are in conformity with the findings of Sharma et al., (2004), Shinde et al., (2006) and Tanpure et al., (2007).

The weight of individual head is also an important parameter which ultimately decides the yield of the cabbage crop (Table 3). The individual head weight was also significantly influenced by different treatments. Most of the fertigation treatments with application of water soluble fertilizers remained on par with each other. However, the maximum head weight was observed with $\mathrm{T}_{3}(454.0 \mathrm{~g})$ followed by $\mathrm{T}_{7}(423.6 \mathrm{~g})$ and $\mathrm{T}_{4}(357.3 \mathrm{~g})$. The treatments, $\mathrm{T}_{10}(238.4 \mathrm{~g}), \mathrm{T}_{1}(234.0 \mathrm{~g})$ and $\mathrm{T}_{2}(237.3 \mathrm{~g})$ had produced significantly lower head weight than $T_{3}$.

Increased nutrient availability in the root zone due to optimum nutrition levels leads to greater absorption and translocation of minerals and nutrients and finally increased accumulation of photosynthates by plants, might be the reasons for higher head weight. These results are corroborated with the findings of Shinde et al., (2006), Tanpure et al., (2007), Imtiyaz et al., (1999), Kumar and Sahu (2013), Mohapatra et al., (2013), Verma et al., (2014), Kumari et al., (2015) and Mankar et al., (2015).

Irrespective of dosage and source of fertilizer, fertigation treatments were significantly superior to conventional soil application treatment with respect to yield. All the fertigation treatments recorded higher yields over the conventional soil application of fertilizers to the tune of $6.5-60.3$ per cent. Among the fertigation treatments, application of 100 per cent fertilizer dose using water soluble fertilizers at weekly interval $\left(T_{3}\right)$ resulted in significantly higher yield (60.86 t $\mathrm{ha}^{-1}$ ) than all the other treatments except the treatment $\mathrm{T}_{7}$, where the bi-weekly application of same amount of fertilizer through the same sources $\left(58.82 \mathrm{t} \mathrm{ha}^{-1}\right)$ and $\mathrm{T}_{4}$ i.e 100 per cent fertilizer dose, but $50 \% \mathrm{~N}$ and $\mathrm{K}$ was applied through water soluble fertilizers (56.94 t ha $\left.{ }^{-1}\right)$ was done. Reducing the dosage of NK or NPK fertigation by 25 per cent reduced the yield substantially.

The interaction of inherent and extraneous factors decides the yield levels of a particular crop. It includes production and mobilization of carbohydrates, water and nutrients uptake from the soil and several other environmental factors to which plants are exposed during the growing period.

Application of nutrients through water soluble fertilizers at different crop growth stages helps in meeting out the nutritional requirements which leads to better and luxurious growth resulted in higher light interception and photosynthates translocation from source to sink for the enhanced yields. These results are in agreement with those reported by Shinde et al., (2006) in cabbage, Kapoor et al., (2014), Chetan and Singh (2011) in cauliflower and Nair et al., (2017) in okra. 
Table.1 Fertigation treatment details in cabbage

\begin{tabular}{|c|c|c|c|c|c|c|c|}
\hline Symbol & Treatment & Fertilizer & Application dose & $\begin{array}{l}\text { Basal dose } \\
\left(\mathrm{kg} \mathrm{ha}^{-1}\right)\end{array}$ & $\begin{array}{c}\text { Top } \\
\text { dressing } \\
\left(\mathrm{kg} \mathrm{ha}^{-1}\right)\end{array}$ & $\begin{array}{c}\text { Fertigaton } \\
\left(\mathrm{kg} \mathrm{ha}^{-1}\right)\end{array}$ & Frequency \\
\hline $\mathbf{T}_{1}$ & \multirow{4}{*}{$\begin{array}{l}100 \% \text { fertilizer dose } \\
\left(150: 100: 125 \mathrm{Kg} \mathrm{ha}^{-1}\right)\end{array}$} & Common & $\begin{array}{l}100 \% \text { soil } \\
\text { application }\end{array}$ & $75: 100: 62.5$ & $75: 100: 62.5$ & - & - \\
\hline $\mathbf{T}_{2}$ & & Common & $50 \%$ NK fertigation & $75: 100: 62.5$ & & $75: 0: 62.5$ & Weekly \\
\hline $\mathbf{T}_{\mathbf{3}}$ & & WSF & $\begin{array}{c}100 \% \text { NPK } \\
\text { fertigation }\end{array}$ & & & $150: 100: 125$ & Weekly \\
\hline $\mathbf{T}_{4}$ & & WSF & $50 \%$ NK fertigation & $75: 100: 62.5$ & & $75: 0: 62.5$ & Weekly \\
\hline $\mathbf{T}_{5}$ & \multirow{2}{*}{$\begin{array}{l}75 \% \text { fertilizer dose } \\
(112.5: 75: 93.75 \mathrm{~kg} \\
\left.\mathrm{ha}^{-1}\right)\end{array}$} & WSF & $\begin{array}{c}100 \% \text { NPK } \\
\text { fertigation }\end{array}$ & & & $\begin{array}{c}112.5: 75: 93.7 \\
5\end{array}$ & Weekly \\
\hline $\mathbf{T}_{6}$ & & WSF & $50 \% \mathrm{NK}$ fertigation & $\begin{array}{l}56.25: 75: 46.8 \\
7\end{array}$ & & $56.25: 0: 46.87$ & Weekly \\
\hline $\mathbf{T}_{7}$ & \multirow[t]{2}{*}{$\begin{array}{l}100 \% \text { fertilizer dose } \\
\left(150: 100: 125 \mathrm{Kg} \mathrm{ha}^{-1}\right)\end{array}$} & WSF & $\begin{array}{l}100 \% \text { NPK } \\
\text { fertigation }\end{array}$ & & & $150: 100: 125$ & Bi-weekly \\
\hline $\mathbf{T}_{\mathbf{8}}$ & & WSF & $50 \% \mathrm{NK}$ fertigation & $75: 100: 62.5$ & & $75: 0: 62.5$ & Bi-weekly \\
\hline $\mathbf{T}_{9}$ & \multirow{2}{*}{$\begin{array}{l}75 \% \text { fertilizer dose } \\
(112.5: 75: 93.75 \mathrm{~kg} \\
\left.\mathrm{ha}^{-1}\right)\end{array}$} & WSF & $\begin{array}{c}100 \% \text { NPK } \\
\text { fertigation }\end{array}$ & & & $\begin{array}{c}112.5: 75: 93.7 \\
5\end{array}$ & Bi-weekly \\
\hline $\mathbf{T}_{10}$ & & WSF & $50 \%$ NK fertigation & $\begin{array}{l}56.25: 75: 46.8 \\
7\end{array}$ & & $56.25: 0: 46.87$ & Bi-weekly \\
\hline
\end{tabular}

WSF: Water soluble fertilizers 
Table.2 Treatment wise fertilizers applied $\left(\mathrm{Kg} \mathrm{ha}^{-1}\right)$ under fertigation in cabbage

\begin{tabular}{|c|c|c|c|c|c|c|c|c|c|}
\hline \multirow[t]{2}{*}{ Treatments } & \multicolumn{3}{|c|}{ Basal dose } & \multicolumn{2}{|c|}{ Top dressing } & \multicolumn{4}{|c|}{ Fertigation } \\
\hline & Urea & $\begin{array}{l}\text { Single super } \\
\text { phosphate }\end{array}$ & $\begin{array}{l}\text { Muriate } \\
\text { of potash }\end{array}$ & Urea & $\begin{array}{l}\text { Muriate } \\
\text { of potash }\end{array}$ & Urea & $\begin{array}{c}\text { Muriate of } \\
\text { potash }\end{array}$ & $\begin{array}{c}\text { Sulphate of } \\
\text { potash }\end{array}$ & 19 All \\
\hline $\mathbf{T}_{1}$ & 163.0 & 625.0 & 104.0 & 163.0 & 104.0 & - & - & - & - \\
\hline $\mathbf{T}_{2}$ & 163.0 & 625.0 & 104.0 & & & 163.0 & 104.0 & - & - \\
\hline $\mathbf{T}_{3}$ & 0.0 & 0.0 & 0.0 & & & 109.0 & & 50.0 & 526.0 \\
\hline $\mathbf{T}_{4}$ & 163.0 & 625.0 & 104.0 & & & 163.0 & & 125.0 & - \\
\hline $\mathbf{T}_{5}$ & 0.0 & 0.0 & 0.0 & & & 81.0 & & 38.0 & 395.0 \\
\hline $\mathbf{T}_{6}$ & 67.5 & 90.0 & 45.0 & & & 122.0 & & 94.0 & - \\
\hline $\mathbf{T}_{7}$ & 0.0 & 0.0 & 0.0 & & & 109.0 & & 50.0 & 526.0 \\
\hline $\mathbf{T}_{8}$ & 163.0 & 625.0 & 104.0 & & & 163.0 & & 125.0 & - \\
\hline $\mathbf{T}_{9}$ & 0.0 & 0.0 & 0.0 & & & 81.0 & & 38.0 & 395.0 \\
\hline$T_{10}$ & 67.5 & 90.0 & 45.0 & & & 122.0 & & 94.0 & - \\
\hline
\end{tabular}

Table.3 Growth and yield parameters of cabbage as influenced by fertigation treatments (Pooled data)

\begin{tabular}{|c|c|c|c|c|c|c|c|c|c|c|c|}
\hline \multirow[t]{2}{*}{ Treatment } & \multicolumn{2}{|c|}{ At 60 DAT } & \multicolumn{7}{|c|}{ At harvest } & \multirow{2}{*}{$\begin{array}{c}\text { WUE } \\
\text { (kg/ha-mm) }\end{array}$} & \multirow{2}{*}{$\begin{array}{c}\text { FUE } \\
(\mathrm{Kg} / \mathrm{kg})\end{array}$} \\
\hline & $\begin{array}{c}\text { Plant } \\
\text { height } \\
(\mathbf{c m})\end{array}$ & $\begin{array}{c}\text { Plant } \\
\text { spread } \\
\text { (cm) }\end{array}$ & $\begin{array}{c}\text { Leaves } \\
\text { per } \\
\text { plant }\end{array}$ & $\begin{array}{c}\text { Leaves } \\
\text { weight } \\
\text { per plant } \\
\text { (g) }\end{array}$ & $\begin{array}{c}\text { Head } \\
\text { weight } \\
\text { (g) }\end{array}$ & $\begin{array}{c}\text { Head } \\
\text { diameter } \\
(\mathrm{cm})\end{array}$ & $\begin{array}{c}\text { Stem } \\
\text { weight } \\
\text { (g) }\end{array}$ & $\begin{array}{c}\text { Root } \\
\text { weight } \\
\text { (g) }\end{array}$ & $\begin{array}{c}\text { Yield (t } \\
\left.\text { ha }^{-1}\right)\end{array}$ & & \\
\hline $\mathbf{T}_{1}$ & 23.59 & 30.65 & 17.67 & 360.0 & 234.0 & 9.93 & 38.3 & 26.33 & 37.96 & 79.08 & 101.23 \\
\hline $\mathbf{T}_{2}$ & 24.74 & 32.26 & 18.67 & 395.0 & 237.3 & 10.76 & 45.0 & 32.67 & 40.39 & 84.14 & 107.71 \\
\hline $\mathbf{T}_{3}$ & 29.56 & 38.33 & 25.67 & 599.3 & 454.0 & 13.30 & 102.3 & 66.67 & 60.86 & 126.79 & 162.29 \\
\hline $\mathbf{T}_{4}$ & 29.23 & 34.27 & 25.00 & 586.0 & 357.3 & 12.88 & 94.0 & 46.33 & 56.94 & 118.62 & 151.84 \\
\hline $\mathbf{T}_{5}$ & 28.76 & 33.77 & 23.33 & 541.6 & 341.0 & 11.96 & 73.3 & 39.00 & 52.59 & 109.56 & 187.15 \\
\hline $\mathbf{T}_{6}$ & 26.01 & 32.46 & 21.67 & 459.7 & 288.3 & 11.72 & 70.0 & 34.33 & 51.74 & 107.79 & 184.13 \\
\hline $\mathbf{T}_{7}$ & 29.34 & 37.47 & 25.33 & 583.3 & 423.6 & 12.99 & 94.0 & 45.67 & 58.82 & 122.54 & 156.85 \\
\hline $\mathbf{T}_{8}$ & 28.80 & 34.61 & 23.67 & 568.6 & 351.7 & 12.43 & 88.3 & 44.33 & 52.41 & 109.18 & 139.76 \\
\hline $\mathbf{T}_{9}$ & 26.82 & 33.82 & 22.33 & 539.0 & 338.0 & 11.78 & 72.7 & 37.33 & 49.72 & 103.58 & 176.94 \\
\hline $\mathrm{T}_{10}$ & 26.09 & 32.53 & 20.00 & 429.0 & 238.4 & 11.51 & 65.6 & 33.33 & 47.06 & 98.04 & 167.47 \\
\hline $\begin{array}{l}\text { CD } \\
(P=0.05)\end{array}$ & 0.780 & 3.26 & 4.59 & 140.16 & 187.7 & 0.472 & 28.79 & 13.35 & 4.06 & & \\
\hline
\end{tabular}


Table.4 Economics of cabbage crop in relation to fertigation treatments

\begin{tabular}{|c|c|c|c|c|c|}
\hline Treatment & $\begin{array}{c}\text { Average } \\
\text { Yield }\left(\mathrm{t} \mathrm{ha}^{-1}\right)\end{array}$ & $\begin{array}{c}\text { Gross } \\
\left.\text { Investment (Rs. ha }{ }^{-1}\right)\end{array}$ & $\begin{array}{l}\text { Gross income } \\
\left(\text { Rs. } \text { ha }^{-1}\right)\end{array}$ & $\begin{array}{l}\text { Net income } \\
\left(\text { Rs. ha } \text { h }^{-1}\right)\end{array}$ & Benefit :cost ratio \\
\hline $\mathbf{T}_{1}$ & 37.96 & 160822 & 379600 & 218778 & 1.36 \\
\hline $\mathbf{T}_{2}$ & 40.39 & 160822 & 403900 & 243078 & 1.51 \\
\hline $\mathbf{T}_{3}$ & 60.86 & 190800 & 608600 & 417800 & 2.19 \\
\hline $\mathbf{T}_{4}$ & 56.94 & 166437 & 569400 & 402963 & 2.42 \\
\hline $\mathbf{T}_{5}$ & 52.59 & 180587 & 525900 & 345313 & 1.91 \\
\hline $\mathbf{T}_{6}$ & 51.74 & 162296 & 517400 & 355104 & 2.19 \\
\hline $\mathbf{T}_{7}$ & 58.82 & 190800 & 588200 & 397400 & 2.08 \\
\hline $\mathbf{T}_{8}$ & 52.41 & 166437 & 524100 & 357663 & 2.15 \\
\hline $\mathbf{T}_{9}$ & 49.72 & 180587 & 497200 & 316613 & 1.75 \\
\hline $\mathbf{T}_{10}$ & 47.06 & 162296 & 470600 & 308304 & 1.90 \\
\hline
\end{tabular}

Sale Price $=$ Rs. $10.00 / \mathrm{kg}$ 
Application of 100 per cent fertilizer dosage through water soluble fertilizers at weekly $\left(\mathrm{T}_{3}\right)$ or bi-weekly $\left(\mathrm{T}_{7}\right)$ interval did not bring significant differences in head yield of cabbage crop and it remained same with 75 per cent of the dosage i.e. $\mathrm{T}_{5}$ and $\mathrm{T}_{9}$. However, reducing the dosage by 25 per cent and applying it through water soluble fertilizers at weekly or bi-weekly interval made a significant difference in yield levels. Similarly, significant differences were recorded between application of 50 per cent of NK amount at 100 and 75 per cent fertilizer dosage through fertigation at weekly as well as bi-weekly intervals.

\section{Water Use Efficiency}

Data pertaining to water use efficiency in cabbage is presented in Table 3 . It is clearly evident from the results that all the fertigation treatments using water soluble fertilizers produced higher water use efficiency to the tune of 6.39 to 60.33 per cent compared to conventional method of fertilizer application (79.08 kg/ha-mm). Among fertigation treatments, $\mathrm{T}_{3}$ i.e. application of 100 per cent NPK fertigation using water soluble fertilizers on weekly basis, recorded the highest water use efficiency of $126.79 \mathrm{~kg} / \mathrm{ha}-\mathrm{mm}$ followed by same amount of fertilizer given on biweekly basis ( $\left.\mathrm{T}_{7}: 122.54 \mathrm{~kg} / \mathrm{ha}-\mathrm{mm}\right)$. This was mainly due to maximum cabbage head yield recorded with same amount of irrigation water used. This is in confirmation with the findings of Kapoor et al., (2014) in cauliflower, Chand (2014) in salad cucumber, Soumya et al., (2008) in tomato, Mahendran et al., (2011) and Nair et al., (2017) in okra. Cutting across the level and frequency of fertigation, NPK fertigation in general resulted in marginally superior water use efficiency $(109.18$ - $126.79 \mathrm{~kg} / \mathrm{ha}-\mathrm{mm})$ over NK fertigation treatments (98.04 - 109.56 $\mathrm{kg} / \mathrm{ha}-\mathrm{mm})$.

\section{Fertilizer use efficiency}

Though the $\mathrm{T}_{3}$ recorded highest yield $(60.86 \mathrm{t}$ $\left.\mathrm{ha}^{-1}\right)$ and water use efficiency $(126.79 \mathrm{~kg} / \mathrm{ha}-$ $\mathrm{mm})$, the application of 25 per cent less amount of fertilizer dosage in the form of water soluble fertilizes given either 100 per cent NPK of 50 per cent NK on weekly and bi-weekly basis through fertigation resulted in higher fertilizer use efficiency (167.47 to $187.15 \mathrm{~kg} / \mathrm{kg}$ ). Soil application or fertigation with normal fertilizers gave the minimum values for fertilizer use efficiency of 101.23 and $107.71 \mathrm{~kg} / \mathrm{kg}$. Vasu and Reddy (2013) also recorded higher fertilizer use efficiency at lower rate of fertilizer dose in cabbage.

\section{Economics}

The averaged data pertaining to economic returns and benefit: cost ratio related to 'Unnati' a cultivar of cabbage for the year 2013 and 2014 are given in Table 4. All the fertigation treatments with water soluble fertilizers resulted in higher gross income than soil application $\left(\mathrm{T}_{1}\right)$ and fertigation with common fertilizers $\left(\mathrm{T}_{2}\right)$. Among the fertigation treatments, application of 100 per cent fertilizer dose through fertigation on weekly basis $\left(\mathrm{T}_{3}\right)$ has resulted in highest gross income (Rs.608600 ha ${ }^{-1}$ ) followed by $\mathrm{T}_{7}$ i.e. same amount of fertilizer given on bi-weekly basis (Rs.588200 ha ${ }^{-1}$ ). As far as net income is concerned, the higher values were recorded with $\mathrm{T}_{3}$ (Rs.417800 ha ${ }^{-1}$ ) and $\mathrm{T}_{4}$ (Rs.402963 $\left.\mathrm{ha}^{-1}\right)$. Fertigation of 50 per cent amount of $\mathrm{N}$ and $\mathrm{K}$ of the 100 per cent fertilizer dose through water soluble fertilizers $\left(\mathrm{T}_{4}\right)$ has recorded the highest $\mathrm{B}: \mathrm{C}$ ratio of 2.42 . This is mainly due to less gross investment coupled with moderately higher levels of yield compared to other treatments. Because of this, in other treatments, wherever 50 per cent amount of $\mathrm{N}$ and $\mathrm{K}$ applied through fertigation and reaming 50 per cent through soil application resulted in moderately higher 
B:C ratio, which ranged from 1.90 to 2.19 , irrespective of weekly or bi-weekly applications. Vasu and Reddy (2013) and Bhoutekar et al., (2017) recorded higher B:C ratio with higher doses of fertilizer where the $\mathrm{N}$ and $\mathrm{K}$ was given through fertigation in cabbage and cauliflower, respectively. Nair et al., (2017) also observed the same results in okra.

From this study it can be concluded that application of water soluble fertilizers @ 150:100:125 kg NPK $\mathrm{ha}^{-1}$ during the cropping period through fertigation at weekly intervals resulted in higher yield and net income in rabi grown cabbage. However, higher $\mathrm{B}: \mathrm{C}$ ratio was obtained with fertigation of 75:0:62.5 NPK $\mathrm{ha}^{-1}$ at weekly intervals along with soil application of 75:100:62.5 NPK ha $^{-1}$ as basal dose.

\section{References}

Bhoutekar Savita, Saikia Luchon, Gogoi Bonti and Chack Sonbeer. 2017. Fertigation level and mulching in cauliflower (Brassica oleracea L. var. botrytis) $\quad c v$. Snowball white. International J. of Agri. Sci., 9(21): 4226-4228

Chand, A.R.J. 2014. Nutrient use efficiency and economics of salad cucumber using drip fertigation in naturally ventilated polyhouse. J. Agri. and Vet. Sci., 7(12): 22-25.

Chetan, S. and Singh, K.G. 2011. Crop water requirements and fertigation options for early drip irrigated cauliflower (Brassica oleracea var. botrytis Linn.) grown in a greenhouse. Prog. Hort., 43(1): 99-101.

Gomez, K. A. and Gomez, A, A, 1983. Statistical procedure for agricultural research. Second edition. WileyInternational Science Publication. New York, United States of America.
Hanif, R., Iqbal, Z., Iqbal, M., Hanif, S. and Rasheed, M. 2006. Use of vegetables in food: Role in human health. $J$. Agril. and Bio. Sci., 1, 18-22

Imtiyaz, M., Mgadla, N. P. and Manase, S. K.1999. Drip irrigation scheduling for cabbage under semi-arid climate. Trop. Agril., 78(2): 99-103.

Kapoor, Renu, Sandal, Sanjeev K., Sharma, Sanjay K., Kumar Anil and Saroch Kapil. 2014. Effect of varying drip irrigation levels and NPK fertigation on soil water dynamics, productivity and water use efficiency of cauliflower (Brassica oleracea var. Botrytis) in wet temperate zone of Himachal Pradesh. Indian J. Soil Cons., 42: 249254

Kumar, P. and Sahu, R. L. 2013. Effect of irrigation and fertigation levels on cabbage. Asian. J. Soil Sci., 8 (2): 270274.

Kumar, S., Singh, J. P., Rajbeer, R. N., Mohan, B., Kaushik, H. and Kumar, D.2013. Influence of integrated nutrient management on growth and yield of cauliflower (Brassica oleracea var. botrytis L.), Int. J. Agric. Sci. 9(2):747-749

Kumari, C., Mankar, A., Karuna, K., Solanki, S. S. and Singh, V. K. 2015. Effect of different levels of nitrogen and microbial inoculants on yield and quality of cabbage. Indian J. Agri. Sci., 85(4): 515-518.

Mahendran, P. P., Arulkumar, D., Gurusamy, A. and Kumar, V. 2011. Performance of nutrient sources and its levels on hybrid bhendi under drip fertigation system. In: Innovation in technology and management of micro-irrigation for crop production enhancement. 8th International Micro-irrigation Congress under 21st International Congress on Irrigation and Drianage, 16-21 October 2011, Tehran, Iran. 
Mankar, A., Kumari, C. and Karuna, K. 2015. Effect of nitrogen levels and microbial inoculants on growth, yield and quality of cabbage. Prog. Hort., 47(2): 296299.

Meena, Yogendra, Sharma,R.K., Kushwah,S.S. and Gallan, Roshan.2017.Effect of varieties and nutrient levels on growth and yield of cauliflower (Brassica oleracea var botrytis L.). The Bioscan, 12(3): 17311734

Mohammadullah Nikzad, J. S. Aravinda Kumar, M. Anjanappa, $\mathrm{H}$. Amarananjundeswara, B. N. Dhananjaya and Basavaraj, G. 2020. Effect of fertigation, levels on growth and yield of cabbage (Brassica oleracea L. var. capitata). Int. J. Curr. Microbiol. App. Sci. 9(01): 1240-1247

Naher, M. N. A., Alam M. N. and Jahan, N.2014. Effect of nutrient management on the growth and yield of cabbage (Brassica oleracea var. capitata L.) in Calcareous Soils of Bangladesh. The Agriculturists 12(2): 24-33

Nair, A.K., Hebbar, S.S., Prabhakar, M. and Rajeshwari, R.S. 2017. Growth and yield performance of okra (Abelmoschus esculentus (L.) Moench.) in relation to fertigation using different rates and sources of fertilizers. Int. J. Curr. Microbiol. App. Sci., 6 (8): 137-143

National Horticulture Board. 2018. Indian Horticulture Database. Ministry of Agriculture, Government of India.

Neeraja, G., Reddy, K. M., Reddy, I. P. and Reddy, Y. N. 1999. Effect of irrigation and nitrogen on growth, yield and yield attributes of Rabi onion (Allium cepa) in Andhra Pradesh. Veg. Sci., 26: 64-68.

Prabhakar, M., Hebbar, S. S. and Nair, A. K. 2010.Production technology of vegetable crops- A hand book. Indian Institute of Horticultural Research, Hessarghatta, Bangalore, Karnataka, pp 87-92.

Rakh, A. J. 1992. Efficiency of liquid fertilizer through drip and surface irrigation method in cabbage (Brassica oleraceae var. capitata L.) in Entisols. M.Sc. (Agri.) Thesis submitted to Mahatma Phule Krishi Vidyapeeth, Rahuri, Maharashtra.

Sanchita, B., Phookan, D. B., Kachari, M., Hazarika, T. K. and Das, K. 2004. Growth, yield and economics of broccoli under different levels of nitrogen fertigation. Hort. Sci., India. 67: 279-282.

Sezen, S.M., Yazar, A. and Eker, S. 2006 Effect of drip irrigation regimes on yield and quality of field grown bell pepper. Agric. Water Manage., 81(12):115-13

Sharma, K.C. and Sharma, L. K. 2010. Effect of bio-fertilizers and NPK levels on growth and yield of mid-maturity group of cauliflower under mid hill sub- humid conditions of Himachal Pradesh. J. Hill Agric., 1 (1) :19-22.

Sharma, V. 2016. Effect of nutrient management on growth and yield of cauliflower (Brassica oleracea var botrytis) inside low cost polyhouse. Himachal J. Agric. Res., 42 (1): 88-92.

Shinde, P. P., Chavan, M. G. and Newase, V. B. 2006. Studies on fertigation in cabbage. J. Maharashtra Agric. Univ., 31(3): 255-257.

Shree, S., Singh, V. K. and Kumar R. 2014.Effect of integrated nutrient management on yield and quality of cauliflower (Brassica oleracea var. botrytis L.). The Bioscan. 9 (3): 10531058

Singandhupe, R.B., James. B.K., Edanna, Anthony, Nanda, P. and Behera, M.S. 2007. Response of fertigation and 
mulching on growth and fruit yield of pointed gourd (Trichosanthes dioica). Indian J. Agric. Sci., 77(1): 8-13.

Singh, R., Chaurasia, S. N. S. and Singh, S. N. 2006. Response of nutrient sources and spacing on growth and yield of broccoli (Brassica oleracea var. italica Plenck). Veg. Sci., 33 (2): 198200.

Singh, S. K., Singh, T., Singh, B. N. and Verma, R. B. 2004.Response of fertility levels and plant density on growth, yield and quality of hybrid cabbage. Veg. Sci., 31(1): 69-72.

Soumya, T. M., Ramachandrappa, B. K. and Nanjappa, H. V. 2008. Effect of fertigation with different sources and levels of fertilizer on growth and yield of tomato. Mysore J. Agril. Sci., 43(1): 80-84.

Spehia, R. S., Sharma, I. P. and Bhardwaj, R. K. 2010. Cost economics and effect of drip irrigation on yield and water use efficiency of okra under mulch and non mulch conditions in mid-hills of Himachal Pradesh. Haryana J. Hort. Sci., 39 (1 \& 2): 161-164.

Tanpure, S. N., Patil, P. V., Pingale, L.V.,
Gutal, G. B. and Bote, N. L. 2007.Effect of different levels of fertilizer application on yield of cabbage. J. Maharashtra Agric. Univ., 32(1): 151-152.

Vasu, D. and Reddy, M.S.2013. Effect of fertigation on yield, quality, nutrient uptake, fertilizer and water use efficiency in cabbage (Brassica oleracea), Agropedology, 23 (2): 106112

Verma, H. and Nawange, D. D., 2015, Effect of different levels of nitrogen and sulphur on the growth, yield and quality of cabbage (Brassica oleracea L. var. capitata). Agric. Sci. Digest., 35(2): 152-154.

Yadav, B.S., G.R. Singh, J.L. Mangal and V.K. Srivastava. 1993. Drip irrigation in vegetable production. Agric. Res. J. 14 (2): 75-82.

Yangalam, S.D and Tumbare, A.D. 2015. Response of cauliflower (Brassica oleracea var. botrytis) to varying irrigation regimes and fertigation levels. Trends in Biosciences, 8 (22): 6110-6115.

\section{How to cite this article:}

Nair, A. K., S. S. Hebbar, M. Prabhakar, M. Senthilkumar and Rajeshwari, R. S. 2020. Performance of Cabbage (Brassica oleracea L. var. capitata) in Relation to Fertigation using Variable Rates and Sources of Fertilizers. Int.J.Curr.Microbiol.App.Sci. 9(11): 940-950. doi: https://doi.org/10.20546/ijcmas.2020.911.112 